\title{
Receptor-receptor interactions in heteroreceptor complexes: a new principle in biology. Focus on their role in learning and memory
}

\author{
Kjell Fuxe ${ }^{1 *}$, Dasiel O. Borroto-Escuela ${ }^{1}$, Francisco Ciruela ${ }^{2}$, Diego Guidolin ${ }^{3}$ and Luigi F. Agnati ${ }^{4}$ \\ *Correspondence: kjell.fuxe@ki.se

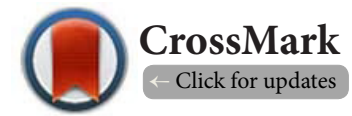 \\ 'Department of Neuroscience, Karolinska Institute, Stockholm, Sweden. \\ ${ }^{2}$ Pharmacology Unit, Faculty of Medicine, Department of Pathology and Experimental Therapeutics, University of Barcelona, \\ L'Hospitalet de Llobregat, Barcelona, Spain. \\ ${ }^{3}$ Department of Molecular Medicine, University of Padova, Padua, Italy. \\ ${ }^{4}$ Department of Biomedical Sciences, University of Modena, Modena, Italy.
}

\begin{abstract}
The allosteric receptor-receptor interactions over the interfaces in heteroreceptor complexes have been explored and their biochemical, pharmacological and functional integrative implications in the Central Nervous System (CNS) described. GPCR interacting proteins participate in these complexes mainly through modulation of receptor-receptor interactions. Methodologies to study heteroreceptor complexes in living cells (FRET and BRET-based techniques) and in brain tissue (in situ proximity ligation assay) are briefly summarized. The physiological and pathological relevance of the allosteric receptor-receptor interactions in heteroreceptor complexes is emphasized and novel strategies for treatment of mental and neurological disease are developed based on this new biological principle of integration. The molecular basis of learning and memory is proposed to be based on the reorganization of the homo- and heteroreceptor complexes in the postjunctional membrane of synapses leading also to changes in the prejunctional receptor complexes to facilitate the pattern of transmitter release to be learned. Long-term memory may be created by the transformation of parts of the heteroreceptor complexes into unique transcription factors which can lead to the formation of specific adapter proteins which can consolidate the heteroreceptor complexes into long-lived complexes with conserved allosteric receptor-receptor interactions.
\end{abstract}

Keywords: G protein coupled receptor, dimerization, in situ proximity ligation assay, allosteric receptorreceptor interactions, learning, memory, heteroreceptor complexes, mental and neurological disease.

\section{Introduction}

In the early 1980's we observed that neuropeptides can alter the affinity and density of the monoamine agonist and antagonist binding sites in different regions of the CNS, in a receptor subtype specific way $[\mathbf{1}, \mathbf{2}]$. This indicated the presence of neuropeptide-monoamine receptor-receptor interactions in the plasma membrane.

The molecular mechanisms for these intramembrane events between neuropeptide and monoamine receptor subtypes were unknown but direct interactions between the two receptors were postulated. In line with our results on neuropeptide induced changes in the affinity of the monoamine receptor subtypes (see also [3,4]), Lefkowitz, Limbird and colleagues had earlier discovered negative cooperativity in beta adrenergic receptors $[5,6]$. This can be explained on the basis of the existence of beta adrenergic homodimers leading to site-site interactions. The first symposium on receptor-receptor interactions among GPCRs was held in Stockholm in 1986 [7]. In the preface to the symposium book the receptor-receptor interaction field was proposed to become wider and include also interactions between different classes of biologically active macromolecules such as receptors, ion channels and ion pumps.

Receptor heteromerization was postulated in 1993 to be the molecular basis for the receptor-receptor interaction [8]. The first 
Fuxe et al. Neuroscience Discovery 2014,

observations indicating the existence of homodimerization of GPCR were made in 1982 [9,10]. In 1987 homodimerization was found to take place upon epidermal growth factor (EGF) induced stimulation of the epidermal growth hormone receptor [11]. Ten years later the demonstration of the GABA B receptor heterodimer (see [12-14]) validated our early findings indicating receptor-receptor interactions in putative GPCR heteroreceptor complexes $[\mathbf{2}, \mathbf{8}]$. Thus, the entire decoding process becomes a branched process already at the receptor level in the plasma membrane. For a review of the early work on receptor-receptor interactions, see [15].

The allosteric receptor-receptor interactions over the interfaces in heteroreceptor complexes and their biochemical, pharmacological and functional integrative implications in the CNS will be dealt with in this review. The resemblance of the receptor protomers to moonlighting proteins $[16,17]$ will be underlined. Heteroreceptor complexes appear to be a fundamental principle for molecular integration in biology. The involvement of GPCR interacting proteins in these heteroreceptor complexes will also be covered. We will also reveal how the discovery of different types of receptor-receptor interactions in such complexes in the brain led to novel strategies for treatment of Parkinson's disease (e.g., $A_{2 A} R$ and mGluR5 receptor antagonists) [18], schizophrenia (e.g., $A_{2 A} R$ and mGluR5 agonists) $[19,20]$, depression (e.g., $5-\mathrm{HT}_{1 \mathrm{~A}} \mathrm{R}$ agonists enhancing FGFR1 function) [21] and cocaine addiction (e.g., $A_{2 A}$ R agonists) [22]. It contributed to the introduction of $A_{2 A} R$ antagonists in the treatment of Parkinson's disease $[\mathbf{1 8 , 2 3 , 2 4 ]}$.

\section{Review}

Methodologies for studies on protein-protein interactions Fluorescence resonance energy transfer (FRET) and bioluminescence resonance energy transfer (BRET) methods were introduced which could be used to study homo and heteromerization of proteins including receptors in living cells. It involved the preparations of receptor constructs having genetically fused 'donor' and 'acceptor' fluorescent proteins. In FRET if the donor and acceptor fluorophores are in close proximity (less than 10nm) energy transfer between the two fluorophores can occur after donor excitation and acceptor emission develops $[\mathbf{2 5}, \mathbf{2 6}]$. Energy transfer is inversely proportional to the sixth power of the distance $(r)$ between donor and acceptor fluorophors and the distance leading to $50 \%$ of energy transfer from the donor to the acceptor is around $5 \mathrm{~nm}$. There are drawbacks of using classical FRET when the protein is located in intracellular stores, making measurements of protein interactions at the plasma membrane difficult. However, there exist cell surface FRET detection technologies to study GPCR heteromerization in the plasma membrane [27].

The principle of the detection of GPCR heterodimerization using the BRET method is similar to FRET. In the presence of the substrate $\mathrm{h}$-coelenterazine or coelenterazine- 400 on which Renilla luciferase fused to the donor acts to produce through their oxidation a compound showing bioluminence. An energy transfer between the generated luminescence and YFP or GFP2 occurs when the distance between these proteins is less than $10 \mathrm{~nm}$. This leads to a fluorescence emission from YFP $\left(\mathrm{BRET}^{1}\right)$ or $\mathrm{GFP}^{2}\left(\mathrm{BRET}^{2}\right)$ representing the BRET signal. BRET gives strong support for the existence of receptor heteromers in artificial cell systems.

In titration or saturation $\mathrm{BRET}^{2}$ experiments cells are transfected with a constant amount of BRET ${ }^{2}$-donor in presence or absence of increasing amounts of the acceptor. Theoretically, for any specific interaction between the Receptor-donor and Receptor-acceptor fusions, the $\mathrm{BRET}^{2}$ ratio signal is developed as an hyperbole function of GFP/Rluc values, reaching an asymptote (saturation) when all donor molecules are associated with acceptors (BRETmax) [28-30].

Taken together, the use of FRET and BRET-based techniques emerged as important tools in the analysis of GPCR dimerization in living cells. When FRET and BRET-based results are properly evaluated, it is possible to demonstrate clearly an oligomerization of heterologously expressed GPCRs and of cells from transgenic animals [29,31-34]. Consensus exists that FRET and BRET methods powerfully support the existence of receptor heteromers in living cells [35].

Detection of higher order heteroreceptor complexes can be obtained by combined BRET/Bimolecular fluorescence complementation (BiFC) assays in which BiFC is followed by BRET. It may be achieved by combining the bimolecular fluorescence complementation with BRET $[36,37]$. The trimeric heteromers of GPCRs can also be demonstrated with a combination of BRET and FRET. It is called the sequential BRET-FRET technique or SRET technique [38].

In situ Proximity Ligation Assay (in situ PLA) has been performed to establish the existence of native heteroreceptor complexes in the CNS [21,39-41]. In situ PLA is based on a pair of primary antibodies followed by the use of secondary antibodies to which oligonucleotides have been linked. When the two antibodies recognize a dimer, the oligonucleotides of the secondary antibodies are in a sufficiently close proximity (16nm or less) to allow them to recognize each other and join followed by an enzymatic ligation reaction. Then, the DNA circle strand formed can act as a template for an amplification reaction of the rolling circle. It is linked to one of the proximity probes and can be detected and quantified by hybridizing fluorescent oligonucleotides. This sequential reaction process (antibody recognition, joining of oligonucleotides, ligation, amplification and hybridization) rendered the heteroreceptor complexes observable by fluorescence microscopy. In this way you can study the number, localization and modulation of CNS heteroreceptor complexes since formalin fixed tissue is used [21,39-45]. The main drawback of in situ PLA lies in the quality of fixed tissue, the specificity and bivalent character of the primary antibodies and the use of proper controls.

Taken together, the findings indicate that in situ PLA can be used to demonstrate heteroreceptor complexes ex vivo in 
brain tissue like the striatal $A_{2 A} R-D_{2} R$ heteroreceptor complexes $[39,40]$ and the accumbal and dorsal striatal $\mathrm{D}_{2} \mathrm{R}-5 \mathrm{HT}_{2 \mathrm{~A}} \mathrm{R}$ heteroreceptor complexes [42].

\section{GPCR interacting proteins and their receptor-protein interactions}

In the late 1990's the field of GPCR interacting proteins (GIP) started [46-48] substantially adding to the molecular tinkering of GPCRs provided by their oligomerization. Beta-arrestindependent formation of beta2 adrenergic receptor-Src protein kinase complexes was demonstrated [49] as well as Betaarrestin-mediated activation of MAPK by inverse agonists revealing distinct active conformations for $\mathrm{G}$ protein-coupled receptors [50]. PDZ domain-containing proteins known to participate in cellular signaling were shown to bind to GPCRs. The $\mathrm{C}$-terminal motif of the beta 2 adrenergic receptor bound to the first PDZ domain of the $\mathrm{Na} / \mathrm{H}$-exchanger regularity factor modulating the $\mathrm{Na} / \mathrm{H}$ exchange function $[\mathbf{5 1}, \mathbf{5 2}]$ and the $\mathrm{C}$-terminal domain of the $5-\mathrm{HT} 2 \mathrm{C}$ could be linked to the PDZ domain protein MUPP1 [53]. Brakeman and colleagues [54] found that Homer/Vesl proteins can bind to MGluR1a and mGluR5 via an EVH (Enabled/VASP)-like domain. Homer1a is an immediate early protein, increased in seizures and longterm potentiation, and can block the formation of multivalent complexes between group 1 metabotropic glutamate receptors and Homer-related synaptic proteins [55] since it lacks a coiled-coil domain. All homer isoforms can bind to a proline-rich motif in the $\mathrm{C}$-terminal tail of group 1 metabotropic glutamate receptors and those with a coiled-coil domain can link these receptors to $\mathrm{IP}_{3}$ receptors leading to inhibition of $\mathrm{Ca}^{2+}$ release from the latter receptors [56].

In 2003 already 50 or more GPCR interacting proteins (GIPs) had been demonstrated and Bockaert and colleagues $[47,48,57]$ in an interesting review describes the $C$ terminal tail of the GPCRs as the magic tail representing an important anchorage for functional protein networks. Thus, the GPCR structure and function can be regulated through both physical receptor-receptor interactions in homomers and heteromers and through multiple receptor-protein and proteinprotein interactions in higher order structures for molecular integration where the GPCRs in multiple conformational states and stoichiometry are in the center. Many of these GPCR interacting proteins serve as scaffolding or adapter proteins which modulate the physical receptor-receptor interactions in the heteromers [58]. Together with cytoskeletal proteins they also target and anchor the receptor protomes to the plasma membrane [59]. So far the work on receptor-receptor interactions and receptor-protein interactions has mainly been performed in parallel in view of the complexities of the interactions. Overall, GIPs by impinging on the GPCR trafficking, localization and/or pharmacological properties, play a prominent role in GPCR biology including learning and memory (see below) since they fine-tune the receptor functioning [60-62].

\section{Modulation of GPCR biology by GIPs}

GIPs play a critical role in GPCR biology since they accompany receptors along their entire life cycle: from assisting nascent receptors to fold properly and targeting to appropriate subcellular compartments to impinging on their signalling and degradation; thus GIPs are main players of GPCR function [63]. Accordingly, newly synthesized GPCRs at the endoplasmic reticulum (ER) interact with chaperones (e.g., Hsp-40, GRP78, PDI, etc.) which aid folding and maturation of receptors. Without the assistance of these chaperones GPCRs will be either directed to degradation (e.g., proteasomal degradation) or to toxic ER accumulation prompting cell death. Eventually, GPCR misfolding may lead to neuropathology. Overall, appropriate GPCR folding and maturation is critical for GPCR function. Thus, the severe consequences of wrong receptor misfolding are highlighted by the list of pathological conditions associated to intracellular receptor accumulation [64].

Besides interacting with numerous ER-resident folding assistants GPCRs can self associate in the ER forming GPCR homo- and heteromers which under some circumstances might have a chaperone-like activity defining the receptor's export profile $[62,65,66]$. Alternatively, GPCRs can interact in this organelle with accessory proteins (e.g., RAMP, MRAP, RanBP2, MRAP, etc.) which in turn stabilize their structure favouring receptor trafficking. In addition, it has been postulated that some signalling molecules like the $G \beta \gamma$ subunits of the G-protein can also associate with GPCRs at the ER level. Once at the plasma membrane and ready to be challenged GPCRs are yet again readily targeted by GIPs, both on their extracellular and intracellular side. Adenosine deaminase (ADA), apart from being able to deaminate extracellular adenosine, has a nonenzymatical role through direct interaction with adenosine A1 receptors at their extracellular side [58,67-69]. The proposed physiological role of such heterotypic interactions consists in making receptors more sensitive to adenosine through a positive allosteric modulation activity that markedly enhance the receptor's functionality [70-72].

GPCR signalling can also be modulated by intracellular GIPs interacting through the C-terminal tail and the third intracellular loop of the receptor. Thus, GPCRs select their binding partners by recognizing structural features (i.e., protein-recognition domains) located within the target protein. Eventually, these protein-recognition domains can be highly specific such as the PDZ-, the Zinc finger- or the poly proline (PP)-binding domains which are recognized by discrete sequence motifs presented on GPCRs [47]. The PDZ domain-containing proteins include PSD95, NHERF, Shank and MUPP1 among others, and they interact with GPCRs through their conserved PDZ ligand sequence (T/SxV) motif located at the extreme C-terminus of many receptors [47]. Interaction with these GIPs promotes $5-\mathrm{HT}_{2 C} \mathrm{R}$ clustering $[73,74]$, mGluR1/5 anchoring in mature dendritic spines [75], prolongs mGluR5 and $P_{2} Y_{1} R$-mediated signalling [76,77], promotes the coupling of PTH $R$ and LPA $R$ R receptors to Gaq protein $[78,79]$, increases 
Fuxe et al. Neuroscience Discovery 2014,

http://www.hoajonline.com/journals/pdf/2052-6946-2-6.pdf

doi: $10.7243 / 2052-6946-2-6$

GABAB receptor stability [80] and promotes $\mathrm{k}-\mathrm{OPR}$ and $\beta 2-A R$ recycling $[\mathbf{8 1}, \mathbf{8 2}]$.

Another abundant group of GIPs with specific proteinrecognition domains are those that bind proline-rich motifs (e.g., PPSPF) located on either the C-terminal tail or the third intracellular loop of GPCRs (e.g., $a-A R, \beta-A R, D_{4} R, m G l u R 1 / 5$ receptors, etc.) $[47,57]$. These GIPs contain protein modules, for instance the Src Homology (SH) or the WW and Ena/ vasodilator-stimulated phosphoprotein homology 1 (EVH1) domains which bind the corresponding conserved GPCR proline-rich motif and play a critical role in the assembly and regulation of intracellular signalling complexes associated to receptors.

Finally, there are GIPs with less-defined recognition motifs within the GPCR sequence, such as $\beta$-arrestins, where the specific binding relies on receptor phosphorylation events mostly regulated by agonist stimulation. Accordingly, $\beta$-arrestins are considered GIPs that mediate GPCR signalling (i.e., GIP mediators) since its interaction with the receptor is agonist stimulation-dependent, requiring receptor conformational changes [60]. Other GIP mediators are for instance GRKs, G-proteins and even NHERF [51,52]. On the other hand, GIPs that associate with GPCRs in an agonist-independent fashion are considered GIPs that modulate GPCR signalling (i.e., GIP modulators) [60]. Thus, some GIP modulators increase G-protein-mediated signalling by acting as scaffolds (e.g., NHERF, AKAP, etc.) of receptor related signalling proteins and others can reduce G-protein-mediated signalling by disrupting receptor-G-protein association (e.g., spinophilin) or eventually recruiting GPCR signalling negative regulators (i.e., RGS proteins) [60].

Agonist binding to GPCRs triggers not only receptor activation but also receptor desensitization (i.e., rapid attenuation of receptor responsiveness), a phenomenon involving GPCR phosphorylation by GRKs which in turns enhances receptor binding to $\beta$-arrestins, thus making the receptor unavailable for G-protein coupling. The arrestin-bound GPCR may also be internalized, therefore resulting in downregulation of plasma membrane receptors. Accordingly, GPCR internalization is strongly influenced by two of the above mentioned GIPs, the GRKs and arrestins [83]. However, other GIPs can regulate GPCR endocytic trafficking more selectively, for instance GASP which strongly promotes $\delta-O P R, D_{2} R$ and $C B 1$ trafficking to lysosomes after agonist-induced endocytosis [84-86] and SNX1 which binds the PAR1 receptor promoting its post-endocytic trafficking to lysosomes [87]. Overall, it is evident that GIPs play a role in every aspect of GPCR biology: biosynthetic trafficking, anchoring to the site of action, ligand binding, signalling and endocytosis. Therefore, GPCR-mediated signalling is a much more complicated process than described previously since every GPCR requires a set of GIPs which must interact with the receptor in an orchestrated spatio-temporal fashion. Consequently, uncovering the way GIPs impinge into the biology of clinically relevant GPCRs will help understand the formation , structure and function of heteroreceptor complexes.

\section{Targeting GPCRs-GIPs interactions in neurological and mental diseases}

Recently, special attention has been paid to GIPs as they might potentially evolve as drug targets $[\mathbf{5 7 , 6 0 ]}$. Of substantial interest is $\mathrm{p} 11$, an inducible adaptor protein modulating neuronal functions [88]. In depression-like states it has been found to alterate $5-\mathrm{HT}{ }_{1 \mathrm{~B}} \mathrm{R}$ function, modulating its plasma membrane expression [88]. p11 also participates in interactions with the $5-\mathrm{HT}_{4} \mathrm{R}$ contributing to the behavioural effects of $5-\mathrm{HT}_{4} \mathrm{R}$ activation [89].

Spinophilin is a novel protein phosphatase 1 binding protein discovered by Greengard and colleagues and shown to be located in dendritic spines [90] and to interact with $D_{2} R$ and $\mathrm{m}$-opioid receptors [91] and proteins linked to GPCR function. Spinophilin blocks the actions of b-arrestin at GPCR [92]. Of high interest is its modulation of mu opioid receptor signaling, internalization and recycling and deletion of the spinophilin gene increases morphine tolerance and dependence. Spinophilin may represent a new target for treatment of morphine addiction [91].

PICK1 is a perinuclear binding protein and substrate for PKC [93]. PICK1 has been shown to interact with the C-terminal tail region of mGluR7 via the PDZ domain $[57,94]$. An uncoupling of PICK1 from the mGluR7a with an interface interfering peptide produces absence-like seizures, a special form of epilepsy [95].

The examples given above serve to illustrate that GPCRGIP interactions have relevance for neurological and mental diseases. However, their interactions with the allosteric receptor-receptor interactions in heteroreceptor complexes remain to a large extent to be elucidated and can be the targets for drug development.

\section{Allosteric receptor-receptor interactions in GPCR heteroreceptor complexes}

Allosteric waves pass in the interface of the receptor protomers as the transmitter at the orthosteric site or the allosteric modulator at the allosteric site of one receptor protomer causes conformational changes in its protomer. In this way the conformational change can be intermolecularly transferred to the other receptor protomer. In higher order heteroreceptor complexes multiple allosteric receptor-receptor interactions exist $[\mathbf{9 6 , 9 7 ]}$ which likely represent the major molecular mechanism underlying the conformational cafeteria theory of receptors by Kenakin [98]. They will be involved in determining the various conformational states of the receptor protomers and their operation will be determined by the receptor protomer composition, their spatial organization and their order of receptor activation in the higher-order heteroreceptor complex as well as by their interactions with the GPCR interacting proteins (see above). Thus, the receptor protomers may be in different conformations leading to $3 \mathrm{D}$ receptor complexes with different stoichiometry and topology, 
each with a distinct function. Novel functions thus emerge as heteroreceptor complexes are formed or novel allosteric receptor-receptor interactions develop within them as they are targeted by orthosteric agonists/antagonists and allosteric modulators. It gives an increased understanding of their dynamics in terms of, e.g., development of allosteric receptor-receptor interactions. The receptor protomer with regard to its conformational state can also determine the oligomerization state of the receptors e.g., a dimeric, trimeric or tetrameric state. The allosteric receptor-receptor interactions are bidirectional, saturable and show probe dependence [99].

Physiological and pathological relevance of the allosteric receptor-receptor interactions in heteroreceptor complexes Via the allosteric receptor-receptor regulation of heteroreceptor complexes the receptor protomers of these complexes change their function. This may involve alterations of receptor protomer recognition (affinity and receptor density) and of the strength of $\mathrm{G}$ protein coupling leading to modulatory effects on the receptor protomer signaling cascades and on ion channel activity in the plasma membrane like $G$ protein-coupled inwardly-rectifying potassium channels. A major change brought about by the allosteric receptor-receptor interaction is the change of protomer function through a change in its $\mathrm{G}$ protein selectivity from e.g., $\mathrm{Gi}$ to $\mathrm{Gq}$ or favouring receptor protomer signaling over b-arrestin [100-102]. The GPCRs behave as moon-lighting proteins [16] and biased signaling of the GPCR protomers develop [103-105].

Already in the early eighties $[1,2]$ it was underlined that by means of these molecular events it becomes possible for the receptor-receptor interactions in a heteroreceptor complex to filter incoming signals to receptor protomer " $\mathrm{A}$ " based on the change of activity in a second receptor protomer " $\mathrm{B}$ " in the complex which via its interface can transfer the allosteric communication wave to protomer " $A$ ". It should also be considered that any alteration in one of these receptor protomers can cause abnormalities in the recognition of several receptor protomers in higher-order heteroreceptor complexes and in the proper signaling and balance of the multiple effector systems of such receptor complexes.

The receptor-receptor interaction may also make possible the appearance of novel receptor subtypes like the GABA B receptor $[12,13]$. Furthermore, the $A_{1} R-P_{2} Y_{1} R$ heteroreceptor complexes show an $A_{1} R$ with $P_{2} Y_{1} R$ agonist like recognition [106]. Thus, the orthosteric binding sites in the receptor protomers of these complexes change their pharmacology and also recognize novel transmitters. Under pathological conditions dysfunctional receptor protomers may be formed via the interactions with other receptor protomers that should not interact with each other.

The receptor-receptor interactions also have a major impact on receptor cotrafficking like receptor maturation, cell surface expression and internalization [107]. Such events are of high relevance for sensitization and desensitization of receptor protomers in heteroreceptor complexes. Experimental studies for analysis of receptor protomer colocation and cotrafficking including coclustering and cointernalization have been performed inter alia on the $A_{1} R-D_{1} R$ and $A_{2 A} R-D_{2} R$ heteroreceptor complexes $[\mathbf{6 9}, \mathbf{1 0 8 , 1 0 9 ]}$.

\section{Role of allosteric receptor-receptor interactions in hete-} roreceptor complexes in learning and memory

Learning is regarded to occur through changes in the synaptic efficacies via changes in synaptic strength [110]. One molecular basis for learning and memory may be brought about by reorganization of the available higher order heteroreceptor complexes structurally and/or by resetting the multiple allosteric receptor-receptor interactions in these complexes as well as by the formation of novel heteroreceptor complexes via e.g., alterations in the pattern of synaptic and volume transmission signals $[4,111-113]$. Such multiple molecular changes in the heteromers and their receptor-receptor interactions may be the molecular basis for learning and short-term memory, involving multiple changes in the receptor-protein architecture of the heteroreceptor complexes of the postsynaptic membrane as illustrated by the change of barcode (Figure 1). This hypothesis proposes a reorganization of the homo- and heteroreceptor complexes in the postjunctional membrane of synapses in learning and memory leading also to changes in the prejunctional receptor complexes to facilitate the pattern of transmitter release to be learned.

In Figure $1 \mathrm{~A}$ the basal state of the synapse with its postjunctional receptor complexes is shown leading to a defined bar code. Two types of transmitters are indicated to be released from different pools of synaptic vesicles shown in red and green. The vesicles are of different size to indicate the dominance of the transmitter release from the vesicles in green in the basal state.

In Figure 1B learning of a new temporal pattern of release of the two transmitters should take place. In this state the transmitter in red is in dominance as illustrated by the large size of the vesicles with the red transmitter. This pattern is learned by the transient reorganization of the postsynaptic receptor complexes into inter alia higher order heteroreceptor complexes including ion channels,GPCR interacting proteins and homomer-ion channel complexes. This receptor reorganization leads to a novel bar code which can represent a short term memory of the new pattern of transmitter release to be learned which can involve also extrasynaptic receptor complexes. The new pattern of release can be facilitated by the reorganization of the prejunctional receptor complexes through the altered temporal pattern of the transmitters in the synaptic cleft and its surround changing the formation or disrupting the receptor complexes through agonist dependent processes. A retrograde feedback from the new heteroreceptor complexes with a new barcode can also participate. It can involve the release of soluble factors like purines and trophic factors and extracellular vesicles like 
Fuxe et al. Neuroscience Discovery 2014,

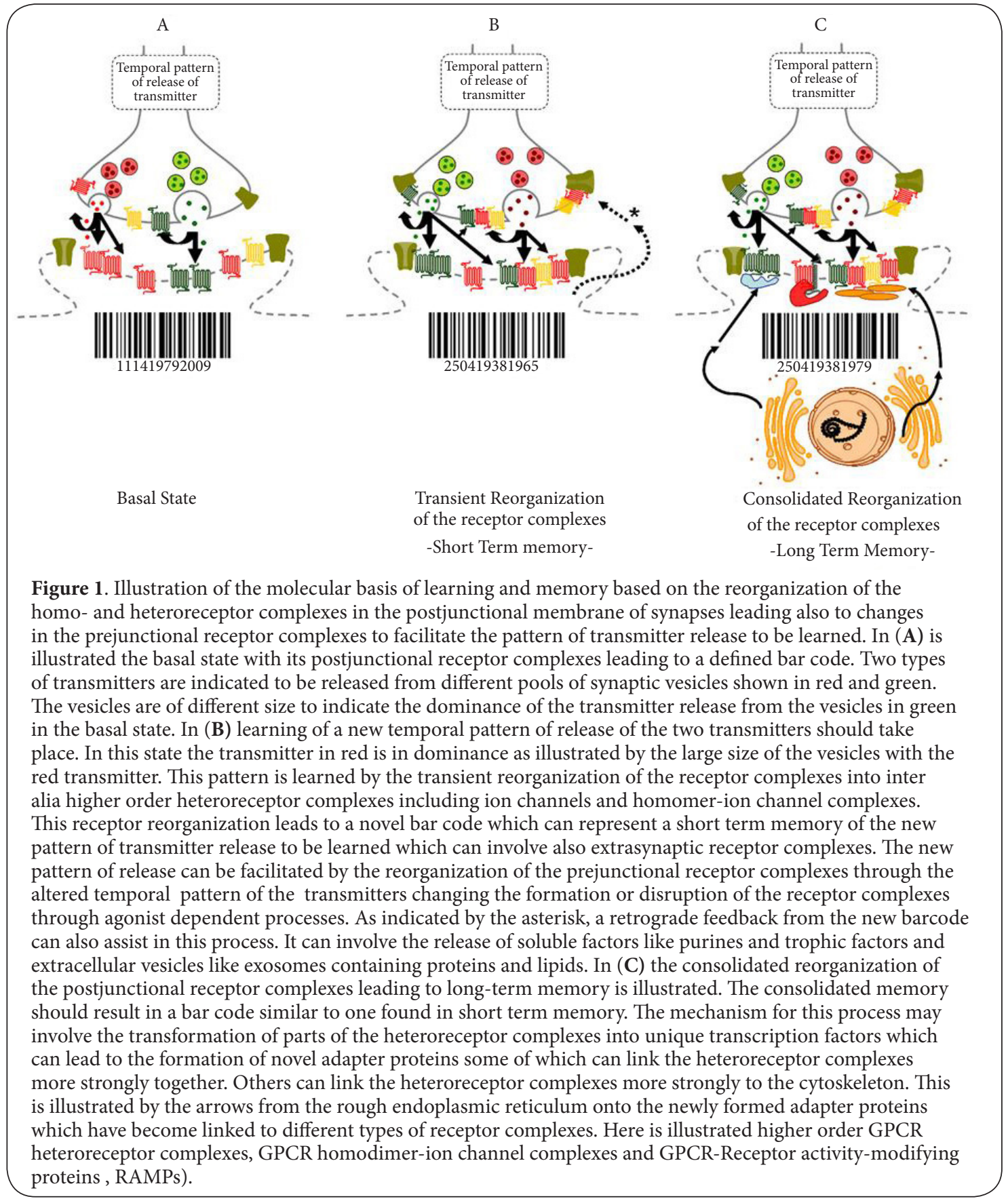

exosomes containing proteins and lipids [114].

In Figure 1C the consolidated reorganization of the postjunctional receptor complexes is illustrated which leads to long-term memory. The consolidated memory is proposed to result in a bar code similar to one found in short term memory. The mechanism may include the transformation of parts of the heteroreceptor complexes into unique transcription factors which can lead to gene expression involving the formation of novel adapter proteins. These can bind to the heteroreceptor complexes of short term memory and consolidate them. Others can link the heteroreceptor complexes more strongly to the cytoskeleton involving also the GPCR interacting proteins. This process is illustrated by the arrows from the rough endoplasmic reticulum onto the newly formed adapter proteins which have become directly linked to different types of postsynaptic and extrasynaptic receptor complexes (Figure 1C). Higher order GPCR heteroreceptor complexes, GPCR homodimer-ion channel complexes and GPCR-Receptor activity-modifying proteins (RAMPs) are shown. Local protein synthesis via translational activation of mRNA in the synaptic terminals via receptor 
signaling from the presynaptic membrane may contribute in a similar way to facilitate the consolidation of prejunctional heteroreceptor complexes of short-term memory into longterm memory (see [115]).

Memories are at first fragile and can be disrupted before being stabilized into long-term memories (consolidation) [116]. It is well known that this process relies on the formation of new proteins [117]. Thus, the long-term memory involves consolidation and the hypothesis (see above) emphasizes that transcription factors can be formed from internalized heteroreceptor complexes induced by the repeated activation of the novel or altered transient complexes and their receptor interacting proteins and signaling cascades towards the nucleus. As discussed, this can lead to the production of unique transcription factors formed from internalized receptor heteromers. It results in the formation of unique adapter and scaffolding proteins which stabilize the heteroreceptor complexes by binding to them. In this way long-lived heteroreceptor complexes are formed involving e.g., GPCR, ion channel receptors and tyrosine receptor kinases (RTK) also linked to ion channels where the consolidated heteroreceptor complexes represent the long-term memory (Figure 1C). It shows a barcode similar to the one for the short-term memory (Figure 1B). Phosphorylation events can participate in this memory process via enabling stronger electrostatic epitopeepitope interactions in the heteroreceptor complexes $[118,119]$.

It may also be considered that further consolidation of these stabilized heteroreceptor complexes may take place by the ability of the unique adapter proteins to cause a constitutive activity of one of the receptor protomers. Ordered activation of the heteroreceptor complexes may in this way be achieved with repetition of the sequence of ion fluxes, and chemical signaling cascades including metabolic cascades. In this way the transcriptional panorama can to some degree remain with maintained formation of the unique adapter proteins leading to maintenance of the higher order heteroreceptor complexes and keeping the long-term memory intact. However, long term memories may transiently move into a fragile state when retrieved and for restabilization newly formed proteins are needed [120-122]. Reconsolidation takes place when new learning is offered during reactivation making possible an update of the memories giving the opportunity to erase memories of the past [123]. According to our hypothesis of the engram this relearning process at the molecular level involves the reorganization of the old heteroreceptor complexes to which the old adapter proteins can no longer bind. Instead novel transcription factors are formed from parts of the new heteroreceptor complex leading to formation of unique adapter proteins which can bind to the new heteroreceptor complexes. This leads to the formation of new long-term memories and disappearance of the old ones.

This hypothesis on the molecular basis of the engram is in line with the Hebbian rule. Thus, memory formation is linked to simultaneous firing of the pre and postsynaptic nerve cells leading to potential short- and long-term memory formation due to changes in the function of the postsynaptic neurons [124]. A molecular basis of this rule can be obtained by proposing that the repeated temporal pattern of a transmitter code in the synaptic cleft can produce a unique firing pattern in the postsynaptic nerve cell. Transcriptional and gene expression activities makes it possible due to the formation and resetting of multiple heteroreceptor complexes in the postsynaptic membrane $[4,111-113]$. Rapid and transient changes in the heteroreceptor complexes which involves also formation of novel heteroreceptor complexes can also take place in the presynaptic membrane in order to favour the pattern and amount of neurotransmitter and modulator release to be learnt. Activation of prejunctional receptors via pre and postsynaptic VT and synaptic signals including retrograde signals may importantly contribute to the plasticity changes in the presynaptic heteroreceptor complexes. Through local protein synthesis in the synaptic terminal these prejunctional receptor complexes can become consolidated into long-term memory traces ( see above).

Subsequently, novel adapter and scaffolding proteins may be formed through local gene expression in nerve terminals from mRNA [115] to form long-lived heteroreceptor complexes in the presynaptic membrane converging short term memories into long term memories as postulated to take place in the postsynaptic membrane. Such prejunctional heteroreceptor complexes may then precisely set the recruitment of vesicles to the plasma membrane and the amount of extracellular release of neurotransmitters and modulators from vesicles located in the terminal varicosity. This process is linked to the pattern of action potentials that reach and depolarize the terminal membrane.

There may exist both full and/or partial release of the vesicle content of transmitters, which at the nerve terminal can correspond to full and kiss-and-run exocytosis, respectively [125]. These molecular events can thus be regulated by the prejunctional heteroreceptor complexes through receptorvesicular protein interactions which can involve also the neurotransmitter transporters and actin $[126,127]$. The pattern and amount of vesicular release of transmitters to be learnt may also lead to changes in the lipid contents of the plasma membrane which can be of relevance for short term memory formation [128]. Thus, lipid messengers exist like lysophosphatidic acid (LPA) and sphingosine-1-phosphate (S1P) and others, which are activators of rhodopsin family GPCRs located in the plasma membrane [129]. These GPCRs include LPA1-3 and S1P1-5. By such GPCRs for lipid mediators which can be part of the presynaptic heteroreceptor complexes, these changes in lipids can lead to plasticity changes in the presynaptic complexes through allosteric receptor-receptor interactions to assist in learning the new pattern of transmitter release. Short term memories may be formed which can be transformed into long-lived heteroreceptor complexes and thus long-term memories as described above. In these 
Fuxe et al. Neuroscience Discovery 2014,

processes transmitter and modulator VT signals diffusing into synaptic and extrasynaptic regions can play a substantial role by activating their receptor protomers of the heteroreceptor complexes on the pre and postsynaptic membrane including perisynaptic regions. It should be noted that also membrane bound steroid receptor protomers like multiple forms of estrogen receptors can participate in such heteroreceptor processes [130].

\section{Conclusions}

The allosteric receptor-receptor interactions in heteroreceptor complexes appear to represent a new principle in biology making possible integration of signals already at the level of the plasma membrane. These heteroreceptor complexes and their dynamics may be part of the molecular basis of learning and memory. According to our hypothesis long-lived heteroreceptor complexes with stabilized and conserved allosteric receptor-receptor interactions in the postsynaptic membrane can be an essential part of the molecular structure for long-term memory in the neuronal networks. This is made possible through production of unique transcription factors formed from internalized heteroreceptor complexes. It results in the formation of specific adapter and scaffolding proteins which bind to and stabilize the postsynaptic heteroreceptor complexes with conserved allosteric receptor-receptor interactions. The consolidation of prejunctional heteroreceptor complexes of short-term memory into long-term memory by adapter proteins may also take place in order to favour the pattern and amount of neurotransmitter and modulator release to be learnt by the postjunctional heteroreceptor complexes and to help the retrieval of memories from such complexes .

\section{Competing interests}

The authors declare that they have no competing interests.

Authors' contributions

\begin{tabular}{|l|c|c|c|c|c|}
\hline Authors' contributions & KF & DOB & FC & DG & LFA \\
\hline Research concept and design & $\checkmark$ & $\checkmark$ & $\checkmark$ & $\checkmark$ & $\checkmark$ \\
\hline Collection and/or assembly of data & $\checkmark$ & -- & -- & -- & -- \\
\hline Data analysis and interpretation & $\checkmark$ & $\checkmark$ & -- & -- & -- \\
\hline Writing the article & $\checkmark$ & $\checkmark$ & $\checkmark$ & -- & -- \\
\hline Critical revision of the article & $\checkmark$ & $\checkmark$ & -- & -- & -- \\
\hline Final approval of article & -- & -- & -- & $\checkmark$ & $\checkmark$ \\
\hline
\end{tabular}

Acknowledgement and funding

This work has been supported by the Swedish Medical Research Council (62X-00715-50-3) to KF and AFA Försäkring (130328) to KF and DOB-E. DOB-E belong to Academia de Biólogos Cubanos.

Publication history

Editor: C. Shekhar Mayanil, Children's Hospital of Chicago Research Center, USA.

EIC: Tadanori Tomita, Northwestern University Feinberg School of Medicine, USA.

Received: 30-Jul-2014 Final Revised: 08-Sep-2014

Accepted: 17-Sep-2014 Published: 26-Sep-2014

\section{References}

1. Fuxe K, Agnati LF, Benfenati F, Celani M, Zini I, Zoli M and Mutt V. Evidence for the existence of receptor--receptor interactions in the central nervous system. Studies on the regulation of monoamine receptors by neuropeptides. J Neural Transm Suppl. 1983; 18:165-79. I PubMed

2. Fuxe $\mathrm{K}$ and Agnati LF. Receptor-receptor interactions in the central nervous system. A new integrative mechanism in synapses. Med Res Rev. 1985; 5:441-82. | PubMed

3. Fuxe K, Agnati LF, Benfenati F, Cimmino M, Algeri S, Hokfelt T and Mutt $\mathrm{V}$. Modulation by cholecystokinins of $3 \mathrm{H}$-spiroperidol binding in rat striatum: evidence for increased affinity and reduction in the number of binding sites. Acta Physiol Scand. 1981; 113:567-9. | Article I PubMed

4. K. Fuxe, L. Agnati, S.O. Ogren, K. Andersson and F. Benfenati. Neurobiology of central monoamine neurotransmission: functional neuroanatomy and noradrenaline and 5-hydroxytryptamine involvement in learning and memory. in: R. Caputto, C. Marsan (Eds.), Neural transmission, learning and memory, Raven Press, New York, 1983; 237-255.

5. Limbird LE, Meyts PD and Lefkowitz RJ. Beta-adrenergic receptors: evidence for negative cooperativity. Biochem Biophys Res Commun. 1975; 64:1160-8. | Article | PubMed

6. Limbird LE and Lefkowitz RJ. Negative cooperativity among betaadrenergic receptors in frog erythrocyte membranes. J Biol Chem. 1976; 251:5007-14. | Article | PubMed

7. K. Fuxe and L. Agnati. Receptor-receptor interactions. A new intramembrane integrative mechanism, Macmillan Press, London, 1987.

8. Zoli M, Agnati LF, Hedlund PB, Li XM, Ferre S and Fuxe K. Receptorreceptor interactions as an integrative mechanism in nerve cells. $\mathrm{Mol}$ Neurobiol. 1993; 7:293-334. | Article | PubMed

9. Fraser $\mathrm{CM}$ and Venter JC. The size of the mammalian lung beta 2-adrenergic receptor as determined by target size analysis and immunoaffinity chromatography. Biochem Biophys Res Commun. 1982; 109:21-9. | Article | PubMed

10. Paglin S and Jamieson JD. Covalent crosslinking of angiotensin II to its binding sites in rat adrenal membranes. Proc Natl Acad Sci U S A. 1982; 79:3739-43. | Article | PubMed Abstract | PubMed Full Text

11. Yarden $Y$ and Schlessinger J. Epidermal growth factor induces rapid, reversible aggregation of the purified epidermal growth factor receptor. Biochemistry. 1987; 26:1443-51. | Article | P ubMed

12. White JH, Wise A, Main MJ, Green A, Fraser NJ, Disney GH, Barnes AA, Emson $\mathrm{P}$, Foord SM and Marshall FH. Heterodimerization is required for the formation of a functional GABA(B) receptor. Nature. 1998; 396:679-82. | Article | PubMed

13. Marshall FH, White J, Main M, Green A and Wise A. GABA(B) receptors function as heterodimers. Biochem Soc Trans. 1999; 27:530-5. | Pdf | PubMed

14. Marshall FH. Is the GABA B heterodimer a good drug target? J Mol Neurosci. 2005; 26:169-76. | Article | PubMed

15. Agnati LF, Ferre S, Lluis C, Franco R and Fuxe K. Molecular mechanisms and therapeutical implications of intramembrane receptor/receptor interactions among heptahelical receptors with examples from the striatopallidal GABA neurons. Pharmacol Rev. 2003; 55:509-50. | Article I PubMed

16. Jeffery CJ. Moonlighting proteins. Trends Biochem Sci. 1999; 24:8-11. | Article | PubMed

17. Jeffery $\mathrm{CJ}$. Moonlighting proteins: old proteins learning new tricks. Trends Genet. 2003; 19:415-7. | Article | PubMed

18. Fuxe K, Agnati LF, Jacobsen K, Hillion J, Canals M, Torvinen M, TinnerStaines B, Staines W, Rosin D, Terasmaa A, Popoli P, Leo G, Vergoni V, Lluis $C$, Ciruela F, Franco R and Ferre $S$. Receptor heteromerization in adenosine A2A receptor signaling: relevance for striatal function and Parkinson's disease. Neurology. 2003; 61:S19-23. | Article | PubMed 
Fuxe et al. Neuroscience Discovery 2014,

19. Fuxe K, Marcellino D, Woods AS, Giuseppina L, Antonelli T, Ferraro $L$, Tanganelli $S$ and Agnati LF. Integrated signaling in heterodimers and receptor mosaics of different types of GPCRs of the forebrain: relevance for schizophrenia. J Neural Transm. 2009; 116:923-39. Article | PubMed Abstract | PubMed Full Text

20. Fuxe K, Borroto-Escuela DO, Tarakanov AO, Romero-Fernandez W, Ferraro L, Tanganelli S, Perez-Alea M, Di Palma M and Agnati LF. Dopamine D2 heteroreceptor complexes and their receptor-receptor interactions in ventral striatum: novel targets for antipsychotic drugs. Prog Brain Res. 2014; 211:113-39. | Article | PubMed

21. Borroto-Escuela DO, Romero-Fernandez W, Mudo G, Perez-Alea M, Ciruela F, Tarakanov AO, Narvaez M, Di Liberto V, Agnati LF, Belluardo N and Fuxe K. Fibroblast growth factor receptor 1- 5-hydroxytryptamine 1A heteroreceptor complexes and their enhancement of hippocampal plasticity. Biol Psychiatry. 2012; 71:84-91. | Article | PubMed

22. Filip M, Zaniewska M, Frankowska M, Wydra K and Fuxe K. The importance of the adenosine $A(2 A)$ receptor-dopamine $D(2)$ receptor interaction in drug addiction. Curr Med Chem. 2012; 19:317-55. | Article | PubMed

23. Fuxe K, Marcellino D, Genedani S and Agnati L. Adenosine A(2A) receptors, dopamine $D(2)$ receptors and their interactions in Parkinson's disease. Mov Disord. 2007; 22:1990-2017. | Article | PubMed

24. Schwarzschild MA, Agnati L, Fuxe K, Chen JF and Morelli M. Targeting adenosine A2A receptors in Parkinson's disease. Trends Neurosci. 2006; 29:647-54. | Article | PubMed

25. Kaczor AA and Selent J. Oligomerization of $\mathbf{G}$ protein-coupled receptors: biochemical and biophysical methods. Curr Med Chem. 2011; 18:4606-34. | Article | PubMed

26. Castro BM, Torreno-Pina JA, van Zanten TS and Gracia-Parajo MF. Biochemical and imaging methods to study receptor membrane organization and association with lipid rafts. Methods Cell Biol. 2013; 117:105-22. | Article | PubMed

27. Fernandez-Duenas V, Gomez-Soler M, Jacobson KA, Kumar ST, Fuxe $\mathrm{K}$, Borroto-Escuela DO and Ciruela F. Molecular determinants of A2AR-D2R allosterism: role of the intracellular loop 3 of the D2R. J Neurochem. 2012; 123:373-84. | Article | PubMed Abstract | PubMed Full Text

28. Hamdan FF, Percherancier Y, Breton B and Bouvier M. Monitoring protein-protein interactions in living cells by bioluminescence resonance energy transfer (BRET). Curr Protoc Neurosci. 2006; Chapter 5:Unit 5 23. | Article | PubMed

29. Borroto-Escuela DO, Flajolet M, Agnati LF, Greengard P and Fuxe K. Bioluminescence resonance energy transfer methods to study $\mathbf{G}$ protein-coupled receptor-receptor tyrosine kinase heteroreceptor complexes. Methods Cell Biol. 2013; 117:141-64. | Article | PubMed Abstract I PubMed Full Text

30. Borroto-Escuela DO, Garcia-Negredo G, Garriga P, Fuxe K and Ciruela F. The M(5) muscarinic acetylcholine receptor third intracellular loop regulates receptor function and oligomerization. Biochim Biophys Acta. 2010; 1803:813-25. | Article | PubMed

31. Audet M, Lagace M, Silversides DW and Bouvier M. Proteinprotein interactions monitored in cells from transgenic mice using bioluminescence resonance energy transfer. FASEB J. 2010; 24:282938. | Article | PubMed

32. M Bouvier, N Heveker, R Jockers, S Marullo and G Milligan. BRET analysis of GPCR oligomerization: newer does not mean better. Nat Methods. 2007; 4:3-4. | Article

33. Marullo $S$ and Bouvier M. Resonance energy transfer approaches in molecular pharmacology and beyond. Trends Pharmacol Sci. 2007; 28:362-5. | Article | PubMed

34. Pin JP, Neubig R, Bouvier M, Devi L, Filizola M, Javitch JA, Lohse MJ, Milligan G, Palczewski K, Parmentier M and Spedding M. International Union of Basic and Clinical Pharmacology. LXVII. Recommendations for the recognition and nomenclature of $\mathrm{G}$ protein-coupled receptor heteromultimers. Pharmacol Rev. 2007; 59:5-13. | Article | PubMed

35. Ferre S, Baler R, Bouvier M, Caron MG, Devi LA, Durroux T, Fuxe K,
George SR, Javitch JA, Lohse MJ, Mackie K, Milligan G, Pfleger KD, Pin JP, Volkow ND, Waldhoer M, Woods AS and Franco R. Building a new conceptual framework for receptor heteromers. Nat Chem Biol. 2009; 5:131-4. | Article | PubMed Abstract | PubMed Full Text

36. Navarro G, Carriba P, Gandia J, Ciruela F, Casado V, Cortes A, Mallol J, Canela El, Lluis C and Franco R. Detection of heteromers formed by cannabinoid CB1, dopamine D2, and adenosine A2A G-proteincoupled receptors by combining bimolecular fluorescence complementation and bioluminescence energy transfer. ScientificWorldJournal. 2008; 8:1088-97. | Article | PubMed

37. Cabello N, Gandia J, Bertarelli DC, Watanabe M, Lluis C, Franco R, Ferre S, Lujan R and Ciruela F. Metabotropic glutamate type 5, dopamine D2 and adenosine $\mathrm{A} 2 \mathrm{a}$ receptors form higher-order oligomers in living cells. J Neurochem. 2009; 109:1497-507. | Article | PubMed Abstract | PubMed Full Text

38. Carriba P, Navarro G, Ciruela F, Ferre S, Casado V, Agnati L, Cortes A, Mallol J, Fuxe K, Canela EI, Lluis C and Franco R. Detection of heteromerization of more than two proteins by sequential BRET-FRET. Nat Methods. 2008; 5:727-33. | Article | PubMed

39. Trifilieff P, Rives ML, Urizar E, Piskorowski RA, Vishwasrao HD, Castrillon J, Schmauss C, Slattman M, Gullberg M and Javitch JA. Detection of antigen interactions ex vivo by proximity ligation assay: endogenous dopamine D2-adenosine A2A receptor complexes in the striatum. Biotechniques. 2011; 51:111-8. | Article | PubMed

40. Borroto-Escuela DO, Romero-Fernandez W, Garriga P, Ciruela F, Narvaez M, Tarakanov AO, Palkovits M, Agnati LF and Fuxe K. G protein-coupled receptor heterodimerization in the brain. Methods Enzymol. 2013; 521:281-94. | Article | PubMed

41. Borroto-Escuela DO, Van Craenenbroeck K, Romero-Fernandez W, Guidolin D, Woods AS, Rivera A, Haegeman G, Agnati LF, Tarakanov $A O$ and Fuxe K. Dopamine D2 and D4 receptor heteromerization and its allosteric receptor-receptor interactions. Biochem Biophys Res Commun. 2011; 404:928-34. | Article | PubMed

42. Borroto-Escuela DO, Romero-Fernandez W, Narvaez M, Oflijan J, Agnati LF and Fuxe K. Hallucinogenic 5-HT2AR agonists LSD and DOI enhance dopamine D2R protomer recognition and signaling of D2-5-HT2A heteroreceptor complexes. Biochem Biophys Res Commun. 2014; 443:278-84. | Article | PubMed

43. Romero-Fernandez W, Borroto-Escuela DO, Agnati LF and Fuxe K. Evidence for the existence of dopamine D2-oxytocin receptor heteromers in the ventral and dorsal striatum with facilitatory receptor-receptor interactions. Mol Psychiatry. 2013; 18:849-50. | Article | PubMed

44. Soderberg O, Gullberg M, Jarvius M, Ridderstrale K, Leuchowius KJ, Jarvius J, Wester K, Hydbring P, Bahram F, Larsson LG and Landegren $U$. Direct observation of individual endogenous protein complexes in situ by proximity ligation. Nat Methods. 2006; 3:995-1000. | Article | PubMed

45. Soderberg O, Leuchowius KJ, Kamali-Moghaddam M, Jarvius M, Gustafsdottir S, Schallmeiner E, Gullberg M, Jarvius J and Landegren U. Proximity ligation: a specific and versatile tool for the proteomic era. Genet Eng (N Y). 2007; 28:85-93. | Article | PubMed

46. Bockaert J and Pin JP. Molecular tinkering of G protein-coupled receptors: an evolutionary success. EMBO J. 1999; 18:1723-9. | Article | PubMed Abstract | PubMed Full Text

47. Bockaert J, Fagni L, Dumuis A and Marin P. GPCR interacting proteins (GIP). Pharmacol Ther. 2004; 103:203-21. I Article I PubMed

48. Bockaert J, Marin P, Dumuis A and Fagni L. The 'magic tail' of G proteincoupled receptors: an anchorage for functional protein networks. FEBS Lett. 2003; 546:65-72. | Article | PubMed

49. Luttrell LM, Ferguson SS, Daaka Y, Miller WE, Maudsley S, Della Rocca GJ, Lin F, Kawakatsu H, Owada K, Luttrell DK, Caron MG and Lefkowitz RJ. Beta-arrestin-dependent formation of beta2 adrenergic receptorSrc protein kinase complexes. Science. 1999; 283:655-61. | Article | PubMed

50. Azzi M, Charest PG, Angers S, Rousseau G, Kohout T, Bouvier M and Pineyro G. Beta-arrestin-mediated activation of MAPK by inverse 
Fuxe et al. Neuroscience Discovery 2014,

agonists reveals distinct active conformations for $\mathrm{G}$ protein-coupled receptors. Proc Natl Acad Sci U S A. 2003; 100:11406-11. | Article | PubMed Abstract | PubMed Full Text

51. Hall RA, Ostedgaard LS, Premont RT, Blitzer JT, Rahman N, Welsh MJ and Lefkowitz RJ. A C-terminal motif found in the beta2-adrenergic receptor, $\mathrm{P2}$ Y1 receptor and cystic fibrosis transmembrane conductance regulator determines binding to the $\mathrm{Na}+/ \mathrm{H}+$ exchanger regulatory factor family of PDZ proteins. Proc Natl Acad Sci U S A. 1998; 95:8496-501. | Article | PubMed Abstract | PubMed Full Text

52. Hall RA, Premont RT, Chow CW, Blitzer JT, Pitcher JA, Claing A, Stoffel $\mathrm{RH}$, Barak LS, Shenolikar S, Weinman EJ, Grinstein S and Lefkowitz RJ. The beta2-adrenergic receptor interacts with the $\mathrm{Na}+\mathrm{H}+$-exchanger regulatory factor to control $\mathrm{Na}+\mathrm{H}+$ exchange. Nature. 1998; 392:62630. | Article | PubMed

53. Ullmer $\mathrm{C}$, Schmuck K, Figge $\mathrm{A}$ and Lubbert $\mathrm{H}$. Cloning and characterization of MUPP1, a novel PDZ domain protein. FEBS Lett. 1998; 424:63-8. | Article | PubMed

54. Brakeman PR, Lanahan AA, O'Brien R, Roche K, Barnes CA, Huganir RL and Worley PF. Homer: a protein that selectively binds metabotropic glutamate receptors. Nature. 1997; 386:284-8. | Article | PubMed

55. Xiao B, Tu JC, Petralia RS, Yuan JP, Doan A, Breder CD, Ruggiero A, Lanahan AA, Wenthold RJ and Worley PF. Homer regulates the association of group 1 metabotropic glutamate receptors with multivalent complexes of homer-related, synaptic proteins. Neuron. 1998; 21:707-16. | Article | PubMed

56. Tu JC, Xiao B, Yuan JP, Lanahan AA, Leoffert K, Li M, Linden DJ and Worley PF. Homer binds a novel proline-rich motif and links group 1 metabotropic glutamate receptors with IP3 receptors. Neuron. 1998; 21:717-26. | Article | PubMed

57. Bockaert J, Perroy J, Becamel C, Marin P and Fagni L. GPCR interacting proteins (GIPs) in the nervous system: Roles in physiology and pathologies. Annu Rev Pharmacol Toxicol. 2010; 50:89-109. | Article | PubMed

58. Franco R, Ciruela F, Casado V, Cortes A, Canela El, Mallol J, Agnati LF, Ferre $\mathrm{S}$, Fuxe $\mathrm{K}$ and Lluis $\mathrm{C}$. Partners for adenosine $\mathrm{A} 1$ receptors. J Mol Neurosci. 2005; 26:221-32. | Article | PubMed

59. Ciruela F, Canela L, Burgueno J, Soriguera A, Cabello N, Canela El, Casado V, Cortes A, Mallol J, Woods AS, Ferre S, Lluis C and Franco R. Heptaspanning membrane receptors and cytoskeletal/scaffolding proteins: focus on adenosine, dopamine, and metabotropic glutamate receptor function. J Mol Neurosci. 2005; 26:277-92. | Article | PubMed

60. Ritter SL and Hall RA. Fine-tuning of GPCR activity by receptorinteracting proteins. Nat Rev Mol Cell Biol. 2009; 10:819-30. | Article | PubMed Abstract | PubMed Full Text

61. Borroto-Escuela DO, Correia PA, Romero-Fernandez W, Narvaez M, Fuxe K, Ciruela F and Garriga P. Muscarinic receptor family interacting proteins: role in receptor function. J Neurosci Methods. 2011; 195:1619. | Article | PubMed

62. Rondou P, Haegeman G, Vanhoenacker P and Van Craenenbroeck K. BTB Protein KLHL12 targets the dopamine D4 receptor for ubiquitination by a Cul3-based E3 ligase. J Biol Chem. 2008; 283:11083-96. | Article | PubMed Abstract | PubMed Full Text

63. Maurice P, Guillaume JL, Benleulmi-Chaachoua A, Daulat AM, Kamal $M$ and Jockers R. GPCR-interacting proteins, major players of GPCR function. Adv Pharmacol. 2011; 62:349-80. | Article | PubMed

64. Tan CM, Brady AE, Nickols HH, Wang $Q$ and Limbird LE. Membrane trafficking of $G$ protein-coupled receptors. Annu Rev Pharmacol Toxicol. 2004; 44:559-609. | Article | PubMed

65. Van Craenenbroeck K. GPCR oligomerization: contribution to receptor biogenesis. Subcell Biochem. 2012; 63:43-65. | Article | PubMed

66. Van Craenenbroeck K, Borroto-Escuela DO, Romero-Fernandez W, Skieterska K, Rondou P, Lintermans B, Vanhoenacker P, Fuxe K, Ciruela $F$ and Haegeman G. Dopamine D4 receptor oligomerization-contribution to receptor biogenesis. FEBS J. 2011; 278:1333-44. | Article | PubMed

67. Ciruela F, Saura C, Canela EI, Mallol J, Lluis C and Franco R. Adenosine deaminase affects ligand-induced signalling by interacting with cell surface adenosine receptors. FEBS Lett. 1996; 380:219-23. | Article | PubMed

68. Herrera C, Casado V, Ciruela F, Schofield P, Mallol J, Lluis C and Franco R. Adenosine A2B receptors behave as an alternative anchoring protein for cell surface adenosine deaminase in lymphocytes and cultured cells. Mol Pharmacol. 2001; 59:127-34. | Pdf | PubMed

69. Torvinen M, Gines S, Hillion J, Latini S, Canals M, Ciruela F, Bordoni F, Staines W, Pedata F, Agnati LF, Lluis C, Franco R, Ferre S and Fuxe K. Interactions among adenosine deaminase, adenosine $A(1)$ receptors and dopamine $D(1)$ receptors in stably cotransfected fibroblast cells and neurons. Neuroscience. 2002; 113:709-19. | Article | PubMed

70. Gracia E, Cortes A, Meana JJ, Garcia-Sevilla J, Herhsfield MS, Canela El, Mallol J, Lluis C, Franco R and Casado V. Human adenosine deaminase as an allosteric modulator of human $\mathrm{A}(1)$ adenosine receptor: abolishment of negative cooperativity for [H](R)-pia binding to the caudate nucleus. J Neurochem. 2008; 107:161-70. | Article | PubMed

71. Gracia E, Farre D, Cortes A, Ferrer-Costa C, Orozco M, Mallol J, Lluis C, Canela El, McCormick PJ, Franco R, Fanelli F and Casado V. The catalytic site structural gate of adenosine deaminase allosterically modulates ligand binding to adenosine receptors. FASEB J. 2013; 27:1048-61. | Article | PubMed

72. Gracia E, Perez-Capote K, Moreno E, Barkesova J, Mallol J, Lluis C, Franco R, Cortes A, Casado V and Canela El. A2A adenosine receptor ligand binding and signalling is allosterically modulated by adenosine deaminase. Biochem J. 2011; 435:701-9. | Article | PubMed

73. Becamel C, Figge A, Poliak S, Dumuis A, Peles E, Bockaert J, Lubbert $H$ and Ullmer $C$. Interaction of serotonin 5-hydroxytryptamine type $\mathbf{2 C}$ receptors with PDZ10 of the multi-PDZ domain protein MUPP1. J Biol Chem. 2001; 276:12974-82. | Article | PubMed

74. Tobaben S, Sudhof TC and Stahl B. The G protein-coupled receptor CL1 interacts directly with proteins of the Shank family. J Biol Chem. 2000; 275:36204-10. | Article | PubMed

75. Tu JC, Xiao B, Naisbitt S, Yuan JP, Petralia RS, Brakeman P, Doan A, Aakalu VK, Lanahan AA, Sheng M and Worley PF. Coupling of mGluR/ Homer and PSD-95 complexes by the Shank family of postsynaptic density proteins. Neuron. 1999; 23:583-92. | Article | PubMed

76. S R Fam, M Paquet, A M Castleberry, H Oller, C J Lee, S F Traynelis, Y Smith, C C Yun and R A Hall, P2Y1 receptor signaling is controlled by interaction with the PDZ scaffold NHERF-2. Proc Natl Acad Sci U S A. 2005; 102:8042-8047. | Article

77. Paquet $M$, Asay MJ, Fam SR, Inuzuka H, Castleberry AM, Oller H, Smith Y, Yun CC, Traynelis SF and Hall RA. The PDZ scaffold NHERF-2 interacts with mGluR5 and regulates receptor activity. J Biol Chem. 2006; 281:29949-61. | Article | PubMed

78. Mahon MJ, Donowitz M, Yun CC and Segre GV. Na(+)/H(+) exchanger regulatory factor 2 directs parathyroid hormone 1 receptor signalling. Nature. 2002; 417:858-61. | Article | PubMed

79. Oh YS, Jo NW, Choi JW, Kim HS, Seo SW, Kang KO, Hwang JI, Heo K, Kim SH, Kim YH, Kim IH, Kim JH, Banno Y, Ryu SH and Suh PG. NHERF2 specifically interacts with LPA2 receptor and defines the specificity and efficiency of receptor-mediated phospholipase C-beta3 activation. Mol Cell Biol. 2004; 24:5069-79. | Article | PubMed Abstract | PubMed Full Text

80. Balasubramanian S, Fam SR and Hall RA. GABAB receptor association with the PDZ scaffold Mupp1 alters receptor stability and function. J Biol Chem. 2007; 282:4162-71. | Article | PubMed

81. Cao TT, Deacon HW, Reczek D, Bretscher A and von Zastrow M. A kinase-regulated PDZ-domain interaction controls endocytic sorting of the beta2-adrenergic receptor. Nature. 1999; 401:286-90. | Article I PubMed

82. Huang $P$, Steplock D, Weinman EJ, Hall RA, Ding Z, Li J, Wang $Y$ and LiuChen LY. kappa Opioid receptor interacts with $\mathrm{Na}(+) / \mathrm{H}(+)$-exchanger regulatory factor-1/Ezrin-radixin-moesin-binding phosphoprotein-50 (NHERF-1/EBP50) to stimulate $\mathrm{Na}(+) / \mathrm{H}(+)$ exchange independent of G(i)/G(o) proteins. J Biol Chem. 2004; 279:25002-9. | Article | PubMed

83. Reiter $E$ and Lefkowitz RJ. GRKs and beta-arrestins: roles in receptor silencing, trafficking and signaling. Trends Endocrinol Metab. 2006; 
Fuxe et al. Neuroscience Discovery 2014,

\section{7:159-65. | Article | PubMed}

84. Bartlett SE, Enquist J, Hopf FW, Lee JH, Gladher F, Kharazia V, Waldhoer $M$, Mailliard WS, Armstrong R, Bonci A and Whistler JL. Dopamine responsiveness is regulated by targeted sorting of $\mathrm{D} 2$ receptors. Proc Natl Acad Sci U S A. 2005; 102:11521-6. | Article | PubMed Abstract | PubMed Full Text

85. Tappe-Theodor A, Agarwal N, Katona I, Rubino T, Martini L, Swiercz J, Mackie K, Monyer H, Parolaro D, Whistler J, Kuner T and Kuner R. A molecular basis of analgesic tolerance to cannabinoids. J Neurosci. 2007; 27:4165-77. | Article | PubMed

86. Whistler JL, Enquist J, Marley A, Fong J, Gladher F, Tsuruda P, Murray SR and Von Zastrow M. Modulation of postendocytic sorting of $\mathbf{G}$ proteincoupled receptors. Science. 2002; 297:615-20. | Article | PubMed

87. Wang $Y$, Zhou Y, Szabo K, Haft CR and Trejo J. Down-regulation of protease-activated receptor-1 is regulated by sorting nexin 1 . Mol Biol Cell. 2002; 13:1965-76. | Article | PubMed Abstract | PubMed Full Text

88. Svenningsson $P$, Chergui $K$, Rachleff I, Flajolet $M$, Zhang X, El Yacoubi M, Vaugeois JM, Nomikos GG and Greengard P. Alterations in 5-HT1B receptor function by $\mathbf{p} 11$ in depression-like states. Science. 2006; 311:77-80. | Article | PubMed

89. Warner-Schmidt JL, Flajolet M, Maller A, Chen EY, Qi H, Svenningsson $P$ and Greengard P. Role of $\mathrm{p} 11$ in cellular and behavioral effects of 5-HT4 receptor stimulation. J Neurosci. 2009; 29:1937-46. | Article | PubMed

90. Allen PB, Ouimet CC and Greengard P. Spinophilin, a novel protein phosphatase 1 binding protein localized to dendritic spines. Proc Natl Acad Sci U S A. 1997; 94:9956-61. | Article | PubMed Abstract | PubMed Full Text

91. Charlton JJ, Allen PB, Psifogeorgou K, Chakravarty S, Gomes I, Neve RL, Devi LA, Greengard P, Nestler EJ and Zachariou V. Multiple actions of spinophilin regulate mu opioid receptor function. Neuron. 2008; 58:238-47. | Article | PubMed Abstract | PubMed Full Text

92. Wang $Q$, Zhao J, Brady AE, Feng J, Allen PB, Lefkowitz RJ, Greengard $P$ and Limbird LE. Spinophilin blocks arrestin actions in vitro and in vivo at G protein-coupled receptors. Science. 2004; 304:1940-4. | Article | PubMed

93. Staudinger J, Zhou J, Burgess R, Elledge SJ and Olson EN. PICK1: a perinuclear binding protein and substrate for protein kinase $C$ isolated by the yeast two-hybrid system. J Cell Biol. 1995; 128:263-71. | Article | PubMed Abstract | PubMed Full Text

94. El Far O, Airas J, Wischmeyer E, Nehring RB, Karschin A and Betz $\mathrm{H}$. Interaction of the C-terminal tail region of the metabotropic glutamate receptor $\mathbf{7}$ with the protein kinase $\mathbf{C}$ substrate PICK1. Eur J Neurosci. 2000; 12:4215-21. | Article | PubMed

95. Bertaso F, Zhang C, Scheschonka A, de Bock F, Fontanaud P, Marin P, Huganir RL, Betz H, Bockaert J, Fagni L and Lerner-Natoli M. PICK1 uncoupling from mGluR7a causes absence-like seizures. Nat Neurosci. 2008; 11:940-8. | Article | PubMed Abstract | PubMed Full Text

96. Fuxe K, Marcellino D, Borroto-Escuela DO, Frankowska M, Ferraro L, Guidolin D, Ciruela F and Agnati LF. The changing world of $G$ protein-coupled receptors: from monomers to dimers and receptor mosaics with allosteric receptor-receptor interactions. J Recept Signal Transduct Res. 2010; 30:272-83. | Article | PubMed

97. Kenakin T and Miller LJ. Seven transmembrane receptors as shapeshifting proteins: the impact of allosteric modulation and functional selectivity on new drug discovery. Pharmacol Rev. 2010; 62:265-304. | Article | PubMed Abstract | PubMed Full Text

98. Kenakin TP. The secret lives of GPCRs. Drug Discov Today. 2003; 8:674. | Article | PubMed

99. Smith NJ and Milligan G. Allostery at G protein-coupled receptor homo- and heteromers: uncharted pharmacological landscapes. Pharmacol Rev. 2010; 62:701-25 | Article | PubMed Abstract | PubMed Full Text

100. George SR and O'Dowd BF. A novel dopamine receptor signaling unit in brain: heterooligomers of D1 and D2 dopamine receptors ScientificWorldJournal. 2007; 7:58-63. | Article | PubMed
101. Borroto-Escuela DO, Romero-Fernandez W, Tarakanov AO, Ciruela F, Agnati LF and Fuxe K. On the existence of a possible A2A-D2-betaArrestin2 complex: A2A agonist modulation of D2 agonist-induced beta-arrestin2 recruitment. J Mol Biol. 2011; 406:687-99. | Article | PubMed

102. Fuxe K, Borroto-Escuela DO, Romero-Fernandez W, Palkovits M, Tarakanov AO, Ciruela F and Agnati LF. Moonlighting proteins and protein-protein interactions as neurotherapeutic targets in the $g$ protein-coupled receptor field. Neuropsychopharmacology. 2014; 39:131-55. | Article | PubMed

103. Kenakin T. Functional selectivity and biased receptor signaling. $J$ Pharmacol Exp Ther. 2011; 336:296-302. | Article | PubMed

104. Maudsley S. G protein-coupled receptor biased agonism: development towards future selective therapeutics. Mini Rev Med Chem. 2012; 12:803. | Article | PubMed

105. Fuxe K, Tarakanov A, Romero Fernandez W, Ferraro L, Tanganelli S, Filip M, Agnati LF, Garriga P, Diaz-Cabiale Z and Borroto-Escuela DO. Diversity and Bias through Receptor-Receptor Interactions in GPCR Heteroreceptor Complexes. Focus on Examples from Dopamine D2 Receptor Heteromerization. Front Endocrinol (Lausanne). 2014; 5:71. I Article | PubMed Abstract | PubMed Full Text

106. Nakata H, Yoshioka K, Kamiya T, Tsuga $\mathrm{H}$ and Oyanagi K. Functions of heteromeric association between adenosine and $\mathrm{P} 2 \mathrm{Y}$ receptors. J Mol Neurosci. 2005; 26:233-8. | Article I PubMed

107. Bouvier M. Oligomerization of G-protein-coupled transmitter receptors. Nat Rev Neurosci. 2001; 2:274-86. | Article | PubMed

108. Gines S, Hillion J, Torvinen M, Le Crom S, Casado V, Canela El, Rondin S, Lew JY, Watson S, Zoli M, Agnati LF, Verniera P, Lluis C, Ferre S, Fuxe $\mathrm{K}$ and Franco R. Dopamine $\mathrm{D} 1$ and adenosine $\mathrm{A} 1$ receptors form functionally interacting heteromeric complexes. Proc Natl Acad Sci U S A. 2000; 97:8606-11. | Article | PubMed Abstract | PubMed Full Text

109. Hillion J, Canals M, Torvinen M, Casado V, Scott R, Terasmaa A, Hansson A, Watson S, Olah ME, Mallol J, Canela El, Zoli M, Agnati LF, Ibanez CF, Lluis $C$, Franco R, Ferre $S$ and Fuxe K. Coaggregation, cointernalization, and codesensitization of adenosine A2A receptors and dopamine D2 receptors. J Biol Chem. 2002; 277:18091-7. | Article | PubMed

110. Hawkins RD, Kandel ER and Siegelbaum SA. Learning to modulate transmitter release: themes and variations in synaptic plasticity. Annu Rev Neurosci. 1993; 16:625-65. | Article | PubMed

111. Agnati LF, Fuxe K, Zoli M, Rondanini $C$ and Ogren SO. New vistas on synaptic plasticity: the receptor mosaic hypothesis of the engram. Med Biol. 1982; 60:183-90. | PubMed

112. Agnati LF, Franzen O, Ferre S, Leo G, Franco R and Fuxe K. Possible role of intramembrane receptor-receptor interactions in memory and learning via formation of long-lived heteromeric complexes: focus on motor learning in the basal ganglia. J Neural Transm Suppl. 2003; 1-28. I PubMed

113. Fuxe K, Agnati LF and Borroto-Escuela DO. The impact of receptorreceptor interactions in heteroreceptor complexes on brain plasticity. Expert Rev Neurother. 2014; 14:719-21. | Article | PubMed

114. Agnati LF and Fuxe K. Extracellular-vesicle type of volume transmission and tunnelling-nanotube type of wiring transmission add a new dimension to brain neuro-glial networks. Philos Trans $R$ Soc Lond B Biol Sci. 2014; 369. | Article | PubMed

115. Crispino M, Chun JT, Cefaliello C, Perrone Capano C and Giuditta A Local gene expression in nerve endings. Dev Neurobiol. 2014; 74:27991. | Article | PubMed

116. McGaugh JL. Memory consolidation and the amygdala: a systems perspective. Trends Neurosci. 2002; 25:456. | Article I PubMed

117. Kandel ER. The molecular biology of memory storage: a dialogue between genes and synapses. Science. 2001; 294:1030-8. | Article | PubMed

118. Woods AS, Ciruela F, Fuxe K, Agnati LF, Lluis C, Franco R and Ferre $S$. Role of electrostatic interaction in receptor-receptor heteromerization. J Mol Neurosci. 2005; 26:125-32. | Article | PubMed

119. Woods AS and Ferre S. Amazing stability of the arginine-phosphate 
Fuxe et al. Neuroscience Discovery 2014,

http://www.hoajonline.com/journals/pdf/2052-6946-2-6.pdf

electrostatic interaction. J Proteome Res. 2005; 4:1397-402. | Article | PubMed Abstract | PubMed Full Text

120. Nader K, Schafe GE and Le Doux JE. Fear memories require protein synthesis in the amygdala for reconsolidation after retrieval. Nature. 2000; 406:722-6. | Article | PubMed

121. Sara SJ. Retrieval and reconsolidation: toward a neurobiology of remembering. Learn Mem. 2000; 7:73-84. | Article | PubMed

122. Soeter $M$ and Kindt $M$. High trait anxiety: a challenge for disrupting fear memory reconsolidation. PLoS One. 2013; 8:e75239. | Article | PubMed Abstract | PubMed Full Text

123. Sevenster $D$, Beckers $T$ and Kindt M. Prediction error governs pharmacologically induced amnesia for learned fear. Science. 2013; 339:830-3. | Article | PubMed

124. D O Hebb. The organization of behavior. Wiley \& Sons, New York, 1949.

125. Mellander LJ, Kurczy ME, Najafinobar N, Dunevall J, Ewing AG and Cans AS. Two modes of exocytosis in an artificial cell. Sci Rep. 2014; 4:3847. | Article | PubMed Abstract | PubMed Full Text

126. Lee FJ, Pei L, Moszczynska A, Vukusic B, Fletcher PJ and Liu F. Dopamine transporter cell surface localization facilitated by a direct interaction with the dopamine D2 receptor. EMBO J. 2007; 26:2127-36. | Article | PubMed Abstract | PubMed Full Text

127. Trouillon R and Ewing AG. Actin controls the vesicular fraction of dopamine released during extended kiss and run exocytosis. ACS Chem Biol. 2014; 9:812-20. | Article | PubMed

128. Passarelli MK and Ewing AG. Single-cell imaging mass spectrometry. Curr Opin Chem Biol. 2013; 17:854-9. | Article | PubMed

129. Im DS. Discovery of new $G$ protein-coupled receptors for lipid mediators. J Lipid Res. 2004; 45:410-8. | Article | PubMed

130. D O Borroto-Escuela, W Romero-Fernandez, A Rivera, K Van Craenenbroeck, A O Tarakanov, L F Agnati and K Fuxe, On the g-proteincoupled receptor heteromers and their allosteric receptor-receptor interactions in the central nervous system: focus on their role in pain modulation. Evid Based Complement Alternat Med. 2013; 2013: 563716. | Article

\section{Citation:}

Fuxe K, Borroto-Escuela DO, Ciruela F, Guidolin D and Agnati LF. Receptor-receptor interactions in heteroreceptor complexes: a new principle in biology. Focus on their role in learning and memory. Neurosci Discov. 2014; 2:6.

http://dx.doi.org/10.7243/2052-6946-2-6 